\section{B.D.H. Products}

WE have received from the British Drug Houses, Ltd., London, N.1., copies of their catalogues of fine chemical products and micro-analytical reagents and organic reagents for 'spot' tests. The standards of purity adopted for ehemical products are described in the B.D.H. book of A. R. Standards and those for pharmaceutical preparations in the book of P.P.P. (pure for pharmaceutical purposes) Standards. In the case of the latter, other considerations as well as purity must be taken into account, for example, ease of weighing for dispensing, and ready solubility with the formation of a clear bright solution. Low limits for lead and arsenic are defined, being in the case of most substances only a few parts ( 1 to 5 ) in a million. Other metallic impurities may not be physiologically harmful, but may cause precipitation, coloration, or some other reaction and so create difficulties in dispensing : their limits must therefore be fixed as well. The catalogues of fine chemicals run to nearly 150 pages and include lists of standard reagents, indicators, microscopic stains, and dyes. The same firm has also issued recently revised editions of booklets describing their vitamin $A$ and vitamin $D$ preparations, avoleum, radiostol, radiostoleum, and radio-malt. Advance in our knowledge in the vitamin field has been so rapid that frequent revision of brief summaries of this work is required. The activities of the products are controlled by physiological tests and standardised in terms of the international standards wherever such standards are availabie.

\section{Treatment of L eprosy}

Derivatives of chaulmoogra and hydnocarpus oils now have an established position in the treatment of leprosy. The active constituents are certain fatty acids, which are usually administered as their soluble sodium salts or as the ethyl esters. A mixture of esters of the acids of the chaulmoogric series with 0.5 per cent iodine has been recently recommended for the intradermal treatment of the superficial lesions of the disease : the addition of the iodine reduces the irritating properties of the ethyl esters. The intradermal method is relatively free from general and local reactions : rapid resolution of the raised macules, infiltrations, and nodules is reported when small amounts of the solution of esters and iodine are injected into the skin around them. Messrs. Burroughs, Wellcome and Co., London, have issued a solution of these esters with 0.5 per cent iodine, suitable for intradermal and intramuscular administration, under the name "Iodised Moogrol". It is recommended that 5 c.c. be given at weekly intervals : the intradermal injection should be $0 \cdot 1$ c.c. at each point. Intradermal administration should be combined with intramuscular, part of the dose being given by each route.

\section{Oceanography of the Baffin Bay Region}

The United States Coastguard in 1928 sent an expedition in the ship Marion into Davis Strait and Baffin Bay to carry out scientific investigations connected with the international ice patrol, particularly in regard to ocean currents, ocean depths, and ice conditions in the region north of that usually covered by the ice-patrol vessels each spring and summer. The ship followed a zigzag track northward from the Gulf of St. Lawrence to and fro between Labrador, Greenland, and Baffin Island. An account of the expedition and its results are being issued as the U.S. Coastguard Bulletin 19, published in three parts. Part 1 (Washington: Government Printing Office, 1932 ; pp. 81, 50 c.), just issued, contains a fascinating narrative of the cruise, illustrated by 38 well reproduced photographs; it gives also a report and discussion of the sounding work accomplished (by the echo method), and a description and discussion of the bottom samples obtained at some of the places where wire soundings were made. Part 3, published last year, dealt with the arctic ice and its drift into the North Atlantic Ocean, while Part 2, to be issued shortly, will report on the oceanography of Baffin Bay and Davis Strait.

\section{Physiography of the Nile Basin}

IN recent years a great deal of information on the Nile basin, the regime of the Nile, and the control of its floods has been collected by the Irrigation and Physical Department of the Egyptian Ministry of Public Works. This has resulted in a series of valuable papers, including the volumes on the Lake Plateau Basin of the Nile published in 1925 and 1927. This work continues and is being correlated with meteorological and hydrographical work in Uganda and other parts of East Africa. The Irrigation and Physical Department has now published the first of a new series of volumes on the Nile ("The Nile Basin." H. E. Hurst and P. Phillips. Physical Dept. Paper 26. Cairo, 1931. P.T.50). It deals particularly with the topography of the Lake Plateau, Bahr-elJebal, Bahr-el-Ghazel, Sobat basin, and White Nile basin, with a full account of the meteorology of the whole basin. A feature of the book is the large number of coloured folding maps, including maps of the whole basin on a scale of 1 to $2,000,000$. There are also numerous climatic maps and many excellent illustrations. The volume concludes with a long bibliography of the Nile.

\section{Plains of Southern Alberta}

A REGION embracing such well-known names to the petroleum technologist as Calgary, Turner Valley, Bow Island, and Medicine Hat, will always preserve a certain freshness, but more because of its oil and gas industry than on account of any special geological merit. Yet the Alberta Society of Petroleum Geologists has made much lately of its stratigraphy and palæontology, and publications concerning these aspects of research have not been by any means restricted. As is often the case where a sense of vastness seems to engulf human effort, so in the Southern Plains has much of the significance of disconnected work been lost to the wider fraternity of geologists. The Donaldson Bogart Dowling Memorial Symposium on this stratigraphy (Tulsa, Oklahoma: Amer. Assoc. of Pet. Geol.; London : T. Murby and Co. 3 dollars) is not only a happy thought to the memory of a

No. 3276, VoL. 130] 
man who probably knew his "Plains" better than any other, but also a genuine effort at co-ordination and presentation of the results of carefully focused investigations. It might, however, have been substantially improved by a more complete summary of the present position of our knowledge, by way of introduction to the several contributions, than is attempted in the brief foreword; this, though sufficiently lucid so far as it goes, still leaves to the reader the task of fitting together the various pieces of evidence to make a pleasingly intelligent picture of the whole.

\section{Index of Publications of the Royal Society}

THe Royal Society has issued in one alphabet an author index to its Proceedings, Series A and B, from 1905 to 1930 , and to the Philosophical Transactions, Series A and B, from 1901 to the same year, the entries being arranged chronologically under each heading. A previous index to the Proceedings was published in 1913, which covered the period from 1800 (when the series began under the title "Abstracts of Papers printed in the Philosophical Transactions") to the year 1904, so that the author index to this publication is now complete to the year 1930. The only indexes to the Philosophical Transactions hitherto available have been author and subject indexes down to the year 1830, but the "Catalogue of Scientific Papers", which includes papers in the Philosophical Transactions, may be considered to continue the indexing under authors' names down to the year 1900, whence the new volume completes it to the year 1930 . So far as the author index is concerned, therefore, the indexing of the two publications is available for their entire runs. A subject index from 1800 is still lacking, except in so far as the mathematical, mechanical, and physical papers for the period 1800 1900 are concerned, since these have been included in the three published subject indexes to the "Catalogue of Scientific Papers", which covers both publications.

\section{Science and Letters in Poland}

THE principal contribution to vol. 15 of Nauka Polska (Polish Science), which has recently appeared, is Prof. Z. Szweykowski's account of the Institute for the Promotion of Science and Letters in Poland. This Institute, which is to-day under the patronage of Prof. I. Mościcki, the President of the Polish Republic, and himself a distinguished chemist, was founded in 1881 in difficult circumstances from the Mianowski Fund. It has had a chequered history, but the Mianowski Institute now occupies the spacious Staszic Palace, and its future is assured. The aim of this Institute is the furtherance of all branches of science in Poland. It has already published or supported financially the publication of 1200 volumes and the preparation of 200 scientific works, and has subsidised fifty scientific periodicals. In addition, it has made grants to some fifty societies, research laboratories, and museums. The same volume of Nauka Polska includes a comprehensive survey of the progress of science in Poland between 1800 and 1880 by Prof. F.
Bujak. It constitutes a summary of the works of Polish men of science during the greater part of last century. Other articles deal with the present-day needs of applied physics, the position of the State libraries in Poland, and the scope and organisation of the Institute for Slavonic Studies.

\section{Habits of Bats}

IN the Journal of Mammalogy for May (p. 133) Mr. C. E. Johnson gives some notes on a family of red bats (Lasiurus borealis borealis) in captivity, and mentions that theold female, when let looseindoors, alighted more than once on the floor, and rose as easily as a bird. In the eighteenth century, Gilbert White alludes to a tame bat he saw, which several times confuted the vulgar opinion that bats could not rise from a flat surface, by rising with great ease from the floor; and the writer of this note has found the common yellow bat of India (Nycticejus kuhli) and the collared fruitbat of Africa (Rousettus leachi) also quite able to take wing from the flat. These examples are worth giving because the error mentioned by White still persists, and in quarters where 'vulgar opinion' might not be supposed to be the vogue. The fact is that a bat does not voluntarily remain on the flat in the open, but may no doubt be found there unable to rise owing to some incidental disability, just as a man may be found lying helpless on a pavement for a similar reason.

\section{Safety in Mines}

THE Safety in Mines Research Board has recently issued its tenth Annual Report, which contains a good. deal of matter of scientific interest. Perhaps the part that will be most widely read is Appendix No. 9, which refers to researches intended to obviate fatalities from falls of ground. It commences by a record of researches on the strength of supports, etc., carried out under the direction of Prof. S. M. Dixon, and, furthermore, contains summaries of the results obtained by the various district committees working on the subject throughout Great Britain. The body of the Report shows considerable activity on the part of the Board, and indicates how greatly the scope of the work has been extended and how much has been done to make the results accessible to mining men generally. It must, however, be admitted that the work so far has been rather of the nature of collecting scientific material which will, no doubt, be useful at some future date in increasing the safety of mining, for up to the present the results obtained are of scientific interest rather than of practical importance.

\section{American Railway Progress}

THE issue of the Journal of the Franklin Institute for March contains the address of Mr. W. C. Dickerson, president of the American Locomotive Company, on the progress made during the interval 1920-30. The 15 charts reproduced allow it to be readily seen. The weight on the driving wheels of the goods locomotive has increased from 245 to 247 thousand pounds, but the drawbar pull, at 28 miles an hour, from 32 to 50 thousand. For the passenger locomotive the corresponding figures are 192 to 187 and 18 to 44 thousand 